\title{
On Farm Demonstration and Evaluation of Synthetic Insecticides for the Control of Pod Borer (Helicoverpa armigera Hubner) on Chickpea in Bale Zone
}

\author{
Dagne Kora*, Ermias Teshome, Amare Biftu \\ Oromia Agricultural Research Institute, Sinana Agricultural Research Center, Bale-Robe, Ethiopia \\ Email address: \\ dagnekor@gmail.com (D. Kora), ermiastafa@gmail.com (E. Teshome), amarebiftu@gmail.com (A. Biftu) \\ ${ }^{*}$ Corresponding author
}

To cite this article:

Dagne Kora, Ermias Teshome, Amare Biftu. On Farm Demonstration and Evaluation of Synthetic Insecticides for the Control of Pod Borer (Helicoverpa armigera Hubner) on Chickpea in Bale Zone. American Journal of Plant Biology. Vol. 3, No. 3, 2018, pp. $29-32$. doi: 10.11648/j.ajpb.20180303.11

Received: August 15, 2018; Accepted: November 7, 2018; Published: December 3, 2018

\begin{abstract}
Chickpea (Cicer arietinum L.) is the world's second most important grain legumes after common bean (Phaseolus vulgaris L.) among food legumes grown for production worldwide. Ethiopia is considered as secondary center of genetic diversity for chickpea. Field experiment was conducted at two districts with the objectives to demonstrate different insecticide for the control of pod borer on chickpea and to give awareness on the use and effectiveness of the insecticide against pod borer on chick pea. The experiment was conducted using one chickpea variety; Habru (more preferred) and two insecticide Diazenon $(1.2 \mathrm{l} / \mathrm{ha})$ and Karate $(400 \mathrm{ml} / \mathrm{ha})$. The result revealed that both insecticides were effective against pod borer even if they have slight difference on percent larval reductions at both districts. The pod borer damage reduction by different treatments ranged from $71.87 \%$ to $90.63 \%$ and $58.33 \%$ to $66.66 \%$ compared to that in control at Ginir and Goro, respectively. Diazenon resulted maximum seed yield $2610 \mathrm{~kg} / \mathrm{ha}$ and $2200 \mathrm{~kg} / \mathrm{ha}$ at Ginir and Goro, respectively. The plot sprayed with Diazenon gave the maximum net return birr 75,348/ha and 61,120/ha at Ginir and Goro, respectively. It is recommended that these insecticides are suggested to the growers for the management of pod borer population below economic threshold level under field conditions.
\end{abstract}

Keywords: Chickpea, Pod Borer, Helicoverpa armigera, Insecticide, Net Return

\section{Background and Justifications}

Chickpea (CicerarietinumL.) is the world's second most important grain legumes after common bean (PhaseolusvulgarisL.) among food legumes grown for production worldwide [2]. Ethiopia is considered as secondary center of genetic diversity for chickpea and the wild relative of cultivated chickpea (CicerarietinumL.), is found in Tigray region of Ethiopia $[13,6]$. An average chickpea yield in Ethiopia on farmers field is usually below1t/ha although its potential is more than $5 \mathrm{t} / \mathrm{ha}[4,8]$. This is resulted from susceptibility of landraces to frost; drought, water logging and poor cultural practices; low protection measures against weeds, diseases and insect pests $[12,3]$. Chickpea is susceptible to a number of insect pests, which attack on roots, foliage and pods. Gram Pod borer
(Helicoverpa armigera $\mathrm{H}$.) is one of the major insect pests of chickpea and has great economic importance [1]. It is highly polyphagous insect feeding on many other crops such as cotton, tobacco, safflower, tomato, maize, cabbage, peanuts and pulses $[9,5]$ Chickpea pod borer(Helicoverpa armigera Hubner) (Lepidoptera:Noctuidae) is a major field insect pest affecting pulses in several agro-ecological zones. Single larva can damage 40pods and selectively feeds up on growing points and reproductive parts of the host plant. It feeds on floral buds, flowers and young pods of the growing crop [7]. There is a high infestation of pod borer on chickpea, field pea and lentil in three woreda of Bale Zone, namely Goro, Ginnir and Golelcha. Farmers are trying to protect his crops from these pests by spraying different insecticides chemicals purchased from local pesticide dealers and farmers union. The chemical control is still considered as the last resort for 
its management due to their quick known effect [10]. However, wise use of insecticide is the need of the time to avoid their drastic side effects on environment and natural bio control agents [11]. So farmers are asking for effective insecticide chemicals for the management of pod borer and also they asked the frequencies. Most of our farmers have limited information on the use of insecticide for pulse crops. So to alleviate such limitation the activity was initiated with the following objectives:-

1. To demonstrate different insecticide for the control of pod borer of chickpea.

2. To give awareness on the use and effectiveness of the insecticide against pod borer of chickpea.

\section{Materials and Methods}

\subsection{Description of Study Area}

The experiment was done on the farmer's field at two location Ginnir and Goro districts during 2017-2018 crop seasons. The location is suitable for appearance of pod borer every year under natural conditions. The experiment was conducted at Ginir located at 907-2524 meter above sea level receiving mean annual rainfall of $612-1214 \mathrm{~mm}$ and mean annual temperature of $11.31-24.72^{\circ} \mathrm{C}$. Goro located at $1272-$ 3275 meters above sea level receiving mean annual rainfall of $796-1138 \mathrm{~mm}$ and mean annual temperature of 12.93 $22.59^{\circ} \mathrm{C}$ (Adamu Zeleke unpublished survey). Goro is characterized by Chromic Cambi sols soil type and Ginir is characterized PellicVertisols soil type.

\subsection{Treatments and Experimental Design}

The experiment was conducted using one chickpea varieties; Habru (more preferred). Two insecticide Diazenon $(1.21 / \mathrm{ha})$ and Karate $(400 \mathrm{ml} / \mathrm{ha})$ were used in the experiments. The experiment was laid out in none replicated with three plots.

1. Plot one Diazenon sprayed plot

2. Plot two Karate sprayed plot

3. Control(unsprayedplot)

The plots have a size of $100 \mathrm{~m}^{2}(10 \mathrm{~m} \times 10 \mathrm{~m})$. Normal agronomic practices were followed for raising the crop. The insecticide was applied starting from the appearance of the insects.

Data on pod borer population before and after insecticide application was recorded from5 randomly selected plants in each treatment after the emergence of the pod borer. The number of larval population per plant from 5 randomly selected plants in each plot before and after first spray of insecticides was recorded. The reduction percentage of larvae was recorded by counting of larval population over check.

\subsection{Farmers Selection and Evaluations}

Farmers were participated on the evaluations of insecticide against chickpea pod borer. Selection and evaluations was considered on the farmers interests and motivation toward the technology.

$$
\begin{gathered}
\% \text { Larval Reduction }=\frac{\text { larval population on untreated plot }- \text { larval population on treated plot }}{\text { larvalpopulation on untreated plot }} \times 100 \\
\% \text { Yield increased over check }=\frac{\text { larvalpopulationontreatedplot }- \text { larvalpopulationonuntreatedplot }}{\text { larvalpopulationontreatedplot }} \times 100
\end{gathered}
$$

\section{Results and Discussions}

Data collected on the comparative efficacy of two insecticides tested for the management of pod borer on chickpea was presented in tables.

\subsection{Larval Population}

Five plants were randomly selected from each plots and observation were recorded at 7 days intervals. The result revealed that both insecticides were effective against pod borer even if they have different percent larval reductions at both locations. At Ginir the data summarized in table1 revealed that the pest population of Helicoverpa armigera ranged from 1.6 to3.4 larvae per plant before spray and 0.3 to 3.2 after spray during the season. It indicated that the pest was active during December. This period coincided with the flowering and pod formation stage of the crop. The pod borer damage reduction by different treatments ranged from $71.87 \%$ to $90.63 \%$ compared to that in control at Ginir. The highest pod borer larval reduction $(90.63 \%)$ was found in Diazenon sprayed plot followed by Karate $5 \%$ EC (71.87\%) sprayed plot. At Goro the result revealed that both insecticides are effective against pod borer even if they have different percent larval reductions. The data summarized in table 1 revealed that the pest population of Helicoverpa armigera ranged from 1.3 to 3.6 larvae per plant before spray and 0.8 to 2.4 after spray during the season. The pod borer damage reduction by different treatments ranged from $58.33 \%$ to $66.66 \%$ compared to that in control at Goro. The highest pod borer larval reduction $(66.66 \%)$ was found on Diazenon sprayed plot followed by Karate $5 \%$ EC (58.33\%) sprayed plot. 
Table 1. Average Larval Populations of Podborer (Helicoverpa armigera) on Chickpea before and after spray of Insecticides at Ginir and Goro districts in 2017/2018 Cropping Season.

\begin{tabular}{lllll}
\hline \multirow{2}{*}{ Districts } & \multirow{2}{*}{ Insecticide treatments } & \multicolumn{2}{l}{ Mean larval population/plant } & \multirow{2}{*}{$\begin{array}{l}\text { Reduction percentage over } \\
\text { check }\end{array}$} \\
\cline { 3 - 4 } & Before spray & After spray & 90.63 \\
\multirow{3}{*}{ Ginir } & Diazenon & 1.6 & 0.3 & 71.87 \\
& Karate5\% EC & 3.3 & 0.9 & $66.66 \%$ \\
\multirow{3}{*}{ Goro } & Check(no spray) & 3.4 & 3.2 & 58.33 \\
& Diazenon & 3.6 & 0.8 & 1 \\
\hline
\end{tabular}

\subsection{Grain Yields of Chickpea}

The data of seed yields ( $\mathrm{kg} / \mathrm{ha})$ and increased percent over check is presented in table 2. From the result obtained at Ginir, Diazenon resulted maximum seed yield $2610 \mathrm{~kg} / \mathrm{ha}$, followed by Karate $5 \% \mathrm{EC} 1800 \mathrm{~kg} / \mathrm{ha}$, and where as the minimum seed yield $820 \mathrm{~kg} /$ ha on unsprayed plot. Maximum percent of seed yield $(68.58 \%)$ was increased over check by
Diazenon. The second maximum percent of seed yield $(54.44 \%)$ was increased over check by Katare $5 \%$ EC. Again at Goro Diazenon resulted maximum seed yield $2200 \mathrm{~kg} / \mathrm{ha}$, followed by Karate $5 \%$ EC $1600 \mathrm{~kg} / \mathrm{ha}$, and where as the minimum seed yield $600 \mathrm{~kg} / \mathrm{ha}$ on unsprayed plot. Maximum percent of seed yield $(72.73 \%)$ was increased over check by Diazenon. The second maximum percent of seed yield $(62.5 \%)$ was increased over check by Karate $5 \%$.

Table 2. Average Grain Yield of Chick pea at Ginir and Goro districts in 2017/2018 Season. EC.

\begin{tabular}{llll}
\hline \multirow{2}{*}{ Districts } & Insecticide treatments & Grain Yield & Percent yield increased over check \\
\cline { 3 - 4 } & & Kg/ha & +68.58 \\
Ginir & Diazenon & 2610 & +54.44 \\
& Karate5\%EC & 1800 & +72.73 \\
& Check(no spray) & 820 & +62.5 \\
Goro & Diazenon & 1600 & 600 \\
& Karate5\%EC & Check(no spray) & \\
\hline
\end{tabular}

\subsection{Return and benefit cost ratio}

At Ginir the result showed that Diazenon sprayed plot provided the highest gross returns (ETB91350/ha) and the lowest gross return TB28700/ha was computed from untreated check. The plot sprayed with Diazenon gave the maximum net return ETB 75,348/ha and also gave the highest benefit cost ratio (4.7).

The unsprayed plot gave the minimum net returns birr 15,054/ha and gave the lowest benefit cost ratio (1.10). In addition at Goro district Diazenon sprayed plot provided the highest gross returns (ETB77,000/ha) and the lowest gross return ETB21,000/ha was computed from untreated check. The plots prayed with Diazenon gave the maximum net return ETB 61,120/ha and also gave the highest benefit cost ratio (3.85). The unsprayed plot gave the minimum net returns ETB 7,420/ha and gave the lowest benefit cost ratio $(0.55)$.

Table 3. Return and Benefit Cost Ratio of Treatment for the Control of Pod borer in Chickpea during 2017/18 Cropping Season at Ginir and Goro districts.

\begin{tabular}{|c|c|c|c|c|c|c|c|}
\hline Districts & Variety \&Treatment & $\begin{array}{l}\text { Yield obtained } \\
\text { (qt/ha) }\end{array}$ & $\begin{array}{l}\text { Sale price } \\
\text { (ETB/qt) }\end{array}$ & $\begin{array}{l}\text { Total Variable } \\
\text { Cost (ETB/ha) }\end{array}$ & $\begin{array}{l}\text { Gross Return } \\
\text { (Price x Qt) }\end{array}$ & $\begin{array}{l}\text { Net Return } \\
\text { (GR-TVC) }\end{array}$ & $\begin{array}{l}\text { Benefit cost ratio } \\
\text { (NR/TVC) }\end{array}$ \\
\hline \multirow{3}{*}{ Ginir } & Habru + Diazenon & 26.1 & 3500 & 16,002 & 91,350 & 75,348 & 4.71 \\
\hline & Habru+ Karate $5 \%$ & 18 & 3500 & 15,760 & 63,000 & 47,240 & 2.998 \\
\hline & Habru + Nospray & 8.2 & 3500 & 13,646 & 28,700 & 15,054 & 1.10 \\
\hline \multirow{3}{*}{ Goro } & Habru + Diazenon & 22 & 3500 & 15,880 & 77,000 & 61,120 & 3.85 \\
\hline & Habru + Karate $5 \%$ & 16 & 3500 & 15,700 & 56,000 & 40,300 & 2.57 \\
\hline & Habru + Nospray & 6 & 3500 & 13,580 & 21,000 & 7,420 & 0.55 \\
\hline
\end{tabular}

\subsection{Farmers' Perceptions}

About 54 farmers were participated on the evaluation and selection of insecticides at Goro and 56 farmers were participated at Ginir. At both locations the farmers were selected the plot sprayed by Diazenon as their first choice and Karate as a second choice. During the evaluation and selections farmers mostly considers the number of pod damaged per plots. Accordingly they said that the plot with no insecticide applications was more damaged by the larvae as compared to the untreated plot. To avoid the biasness during evaluation and selection farmers haven't get any clue on the sprayed and unsprayed plot. They simply observe the status of the plots only.

\section{Conclusion and Recommendations}

The result revealed that Diazenon and Karate $5 \%$ EC were the most effective insecticides to give high mortality of pod borer on chickpea under field conditions. The most economic 
benefit for pod borer management was obtained from Diazenon sprayed plot and followed by karate sprayed plots. It has been indicated from the present studies that insecticide Deazenon and karate were remained the most effective against pod borer on chickpea and resulted in the maximum reduction percentage of larval population of pod borer on chickpea even if they have slight difference on efficacy at both locations. Farmers should have used both insecticides for the management of pod borer in chickpea. They can be used one insecticide in the absence of the other as an option/alternatives to increase their productivity and also quality.

Therefore, it is suggested/recommended that these effective insecticides were suggested to the growers/farmers or other stake holders for management of the pod borer population below economic threshold level under field conditions.

\section{Acknowledgements}

The activity was funded by USIAD under the ICARDA project and Sinana Agricultural Research Center contributed vehicles for the completion of this work. Both of them are acknowledged.

\section{References}

[1] Ahmed K, Awan MS, 2013. Integerated management of insect pests of chickpea Cicer arietinum (L.) Walp in South Asian Countries: Present status and future strategies-a review. Pak. J. Zool., 45:1125-1145.

[2] Gaur, M. P., Aravind, K. J., and Rajeev, K. V. 2012. A review of impact of Genomic technologies on chickpea breeding strategies. Agronomy, 2:200-203.

[3] Geletu Bejega and Anbessa, Y. 1994. Breeding chickpea for resistance to drought. International symposium on pulse research, April 2-6. New Delhi, India, pp. 145-146.
[4] Jagdish, K., Sethi, S. C., Jonansen, C. T., Kelley, M. R. and Rheene, H. A. 1995. Earliness-acure for most illness of chickpea. P20-23. In: Intentional Chickpea and Pigeonpea Newsletter, ICRISAT, Andhra Pradesh, India.

[5] Javed H, Iqbal J, Khan TM, 2013. Studies on population dynamics of insect pest of safflower, Carthamus tinctorius L. Pak. J. Zool., 45:213-217.

[6] Kanouni, H., Taleei, A. and Okhovat, M. 2011. Aschchyta blight (Ascochyta rabiei(Pass.)Lab.) of Chickpea (CicerarietinumL.):Breeding strategies for resistance. International Journal of plant Breeding and Genetics 5:1-22.

[7] Khan S M, Inayatullah MY, Khan MA, 2009. Varietal screening of chickpea and the efficacy of different insecticides against chickpea pod borer Helicoverpa armigera (hb). Gomal Univ. J. Res., 25: 20-24.

[8] Melese, D. 2005. Morphological and RAPD marker variation analysis in some drought tolerant and susceptible chickpea (CicerarietinumL.) genotypes of Ethiopia. M.Sc Thesis, Addis Ababa University, Ethiopia Pp2-5.

[9] Patankar AG, Giri AP, Harsulkar AM, Sainari MN, Deshpade VV, Ranjekar PK, Gupta VS, 2001. Complexity in specificities and expression of Helicoverpa armigera gut proteinases explains polyphagous nature of insect pest. Insect Biochem. Mol. Biol., 31: 453-464.

[10] Sreekanth M, Lakshmi MSM, Rao YK, 2014. Bio-Efficacy and economics of certain new insecticides against gram pod borer, Helicoverpa armigera (Hubner) infesting Pigeonpea (Cajanus cajan L.). Int. J. Plant Anim. Environ. Sci., 4: 11-15.

[11] Suhail A, Iqbal J, Arshad M, Gogi MD, Arif MJ, Shafait T, 2013. Comparative efficacy of insecticides as seed treatment against wheat aphid and its coccinellid predator. Pak. Entomol., 35: 17-22.

[12] Tilaye, A., Gelatu, B., and Berhe, A., 1994. Role of cool season food legumes and their production constraints in Ethiopia agriculture. Pp. 3-18. In: Cool Season Food Legumes of 67 Ethiopia

[13] Yadeta, A. and Geletu, B. 2002. Evaluation of Ethiopian chickpea landraces for tolerance to drought. Genetic Resources and Crop Evolution 49:557-564. 